\title{
Görsel Sanatlarda Özel Alan ve İktidar İlişkileri
}

\begin{abstract}
Nuray Akkol ${ }^{1}$
$\ddot{O} z$

1970 sonrası düşünürlerin, sanatçlların, özellikle feministlerin toplumsal yapı içinde "özel alanda yaşanan iktidar ilişkileri" açık bir biçimde gündeme getirdikleri bir konudur. Jenny Saville'nin dramatik çözümlemeleri, Şükran Moral, Birgit Jurgensen ve Cindy Sherman'ın yerleşik kültüre açık eleştiri getirmeleri gibi, bir çok sanatcı da işlerinde farklı yöntemler kullanarak eleştirel yapıtlarını oluştururlar.

Bu sanatcılar, çalışmalarında kendilerinin ait oldukları cinsel kimlik sorunlarını da öne çıkararak, günümüzde yaşanan toplumsal cinsiyet kodlarını redderler. Bunu yaparken kadınların içinde bulundukları ve aslında erkeklerin iktidar olmasını amaçlayan hatta onun için kurulmuş gerçeği, sanat yapıtları aracılığıyla güncel pratiklerle sorgulayarak daha geniş bir hesaplaşma başlatırlar. Başlatılan hesaplaşmada, özel alana eleştirel yaklaşılırken, ikili ilişkiler ve aile içi ilişsilerin mahrem yanları öne çıkarılır. Özel alan iliş̧kileri kapsamında yaşananların genellikle gizli ve dokunulmaz nitelikte olması gerçeği, sanatçıları, mahremiyete ve küçükten büyüğe mülkiyet ilişkileriyle hesaplaşmaya götürür.
\end{abstract}

Anahtar Sözcükler: Özel alan, İktidar, Beden, Özne, Cinsel kimlik

\section{Relations between Private Space and Power in Visual Arts}

\begin{abstract}
Absract
"Power relations in the private space" is a subject that started to be precisely brought into question by philosophers, artists and especially feminists in the social structure after 1970. Marlene Dumas's dramatic resolutions, combination of visuality and verbality and Sü̈kran Moral, Birgit Jurgensen and Cindy Sherman's open criticisms about the established cultural state. In their works, these artists reject today's social gender codes by highlighting their own sexual identity problems. While doing this, they start a broader settlement by questioning the states of women, which actually targets the male power, and even the truth that is established for that with current practices through artworks. In these settlements, private aspects of dual relations and intrafamilial relations are brought to forefront while approaching the private space in a critical way. The fact that experiences within private space relations are generally secret and inviolable leads artists to settle with privacy and property relations from minor to major.
\end{abstract}

Keywords: Private area, Power, Body, Subject, Sexual identity.

1 Yrd. Doç. Dr., Çankırı Karatekin Üniversitesi Güzel Sanatlar Fakültesi Resim Bölümü Öğretim Üyesi Tel.03762129411. Mail: nuray.akkol@gmail.com 


\section{Giriş}

Özel alan, kamunun dışında kalan, sadece bireylerin özel yaşamlarının yer aldığı bir alana referans eder. Bu alanın içinde; ikili ilişkiler, aile ve mahrem olan bölümler yer alır. Hebarmas'a göre; “Özel alan bir mahrumiyetin, yoksun kılınmanın alanıdır” ( Savran, 2004, s.106-107).

Özel alan/kamusal alan ayrımı, 1970’lerde feministler tarafından kadınlarla erkekler arasında yaşanan ilişkileri anlamak ve gerekli çerçeveyi ortaya çıkarmak için benimsenmiş bir yaklaşımdı. Elbette egemenlik ilişkisinin devamı olan veya yaşamın her alanına yerleşen bu ilişkileri ele almak, sorgulamak, özellikle kadınların özel alan içinde yaşadıklarını ve bu alanın dokunulmazlığını, eleştirilmezliğini ortadan kaldırmak içindi.

Focuault (2005, s.20)'a göre iktidar bir ilişki ve eylem biçimidir. Ama bu doğrudan doğruya başkaları üzerine değil, başkalarının şimdiki ya da gelecekteki eylemleri üzerinde bir eylemdir”. Diyerek bireylerin ya da grupların davranışlarını yönlendirme biçimi olarak da görür.

Günümüzde yaşanan bu ilişkileri araştırmak, bunlara ait simgeleri, kavramları bulmak, sorgulamak, yeni düşünceler yaratmak, özellikle kadın sanatçıların önemsediği bir durumdur. Ienesko, "Görüntüleri canlandırmak onları etli kemikli kılmak, eşsiz bir serüvendir.” der (Ergüven, 1997, s.7). Bu bağlamda, çalışmada özel alanda yaşanan iktidar ilişkilerinin bir biçimi olan kadının kadın sanatçılar tarafından nasıl ele alındığı üzerinde durulacaktır.

\section{Sanatçılardan Örnekler}

\section{Cindy Sherman}

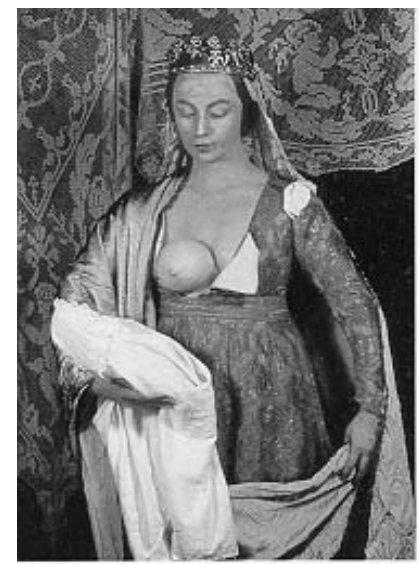

Ciny Sherman, İsimsiz, 1989, Renkli Fotoğraf, 170x142cm

Sherman'ın bu resmi, anne olma durumundaki kadını ele alır. Sanatçının çalışmalarında yapma biçimde meme kullanarak kadının memesinin çocuğunu doyurmaya yarayan bir biberon gibi eşyaya benzetilmesini eleştirdiğini görürüz. Fetişist bir davranış biçimi olan bu durum, kadının sadece organlardan ibaret bir varlık olarak görülmesine, düşünülmesine karşı gerçekleştirilmiş bir protestodur. Kadının, cinsiyle karşılıklı iletişime geçen, ruhsal, düşünsel bir cins olarak düşünülmesinin yerine, sadece görevlerini yerine getiren, hizmet eden ikinci bir cins olarak görülmesinin sonucudur. 
Sherman, çalışmalarında kadın sterotipleri ile ilgilenir. Bunlar sanatçının kadınları nasıl gördüğü anlamında değildir. Daha çok erkeklerin kadınları nasıl gördüğü anlamındadır.

"Bu çalışmalarda güncel kadın imgesi gitmiş, Afrikalı Arap ya da Hint giysileri içindeki egzotik kadın tipleri gelmiştir. Çirkin korkunç, sivilceli ya da cadı kılı̆̆ında, poz veren yine kendisidir." (Honnef, 1990, s.167-168; Y1lmaz 2005, s.319’ ten alınt1 )

\section{Canan Şenol}

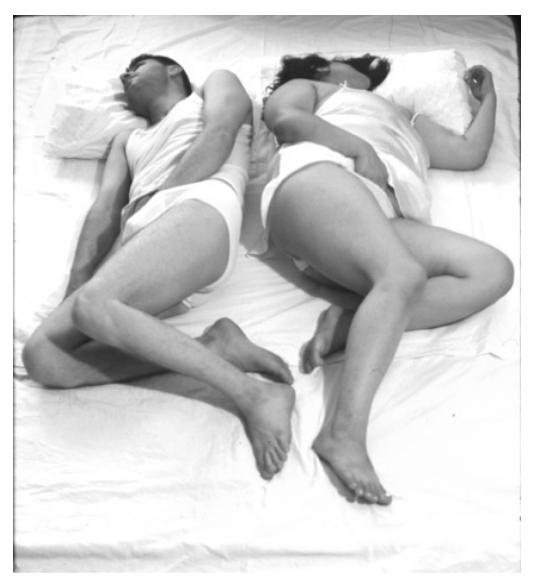

Canan Şenol, 2000 “Ísimsiz”, Fotoğraf, $140 \times 190 \mathrm{~cm}$

Canan Şenol’un “İsimsiz” adlı çalışmasına baktığımızda ikili özel ilişki içinde yer alan başka bir kontrol biçimini ele aldığını görürüz. Burada farklı olan, daha çok dışarının iktidarıyla ilişkinin sırlanmasıdır. Bu çalışmada daha çok iktidarın özel ilişkiyi engellenmenin sınırlanmanın, oluşturduğu bir yok etme noktasıdır. Şenol burada Fucaoult'a bir gönderme yapar gibidir.

"Cinsellik yalnızca suçlanacak ya da hoş görülecek değil; ondan yönetilecek, yaralılık sistemleri içine sokulacak, herkesin azami iyiliği için düzenlenecek, en yüksek verim amaciyla işletilecek bir şey olarak söz etmek gerekmektedir. Cinsellik yalnızca yargılanmaz, yönetilir de kamu gücünün yetkisi dahilinde yer alır." (Foucault, 1993, s.31)

Evlilik; devlet, toplum, din gibi iktidar odakları tarafından kutsanmış, belli bir sistem içine oturtulmuştur. Mahremiyet; iktidar odakları tarafından sınırları çizilmiş bir alandır. İsteyen bu sınırlar içinde bunu yapabilir. Fotoğrafta yan yana yatarak kendilerine dokunan insanları görmek çok basit olsa bile izleyenin görmek istemediği bir durumdur. Zaten kurallar bunu bile yaparken, yasak koyar bunu gizler. Dokunmayacaksın, zevk almayacaksın söylemini, sanatçı bize göstererek sanki bak yaptım, der gibidir.

Sanatçının açıklamaları da bunu destekler. "Yaklaşmayacaksın, dokunmayacaksın, tüketmeyeceksin, haz duymayacaksın, konuşmayacaksın. Ortadan kaldırılmak istemiyorsan kendin vazgeç." (Şenol, 2007). Cinselliğin üzerinde iktidar, salt bir yasaklama yasası uygular. Amacı, cinselliğin kendi kendinden vazgeçmesidir. Aracı, bir cezayla tehdit etmelidir; ceza ise kendisinin ortadan kaldırılmasıdır. 


\section{Jenny Saville}

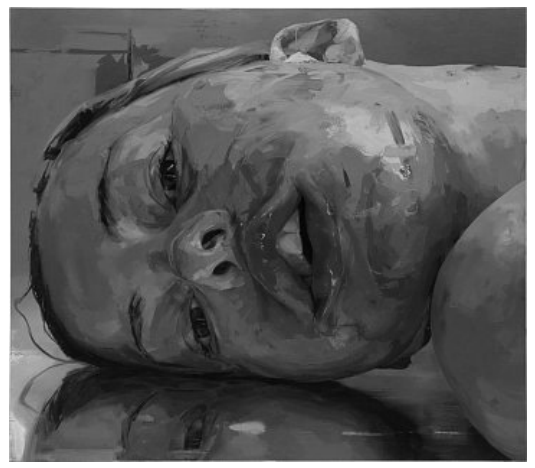

Jenny Saville, 2003, Tuval Üzerine Yă̆lıboya

Saville, resimlerinde daha çok kadın portreleri ve çıplak bedenlerini kullanarak klasik biçimde kadınların bir güzellik nesnesi olarak ele alınmasını eleştirir. Resimlerde açık renkler kullanmak yerine, daha çok renkleri karıştırarak boyayı yoğun, bir biçimde kullanır. Burada daha çok, hoşa giden cezbeden klasik kadın beden anlayışının dışına çıkar. Sanatçı, şişman kadınlara resimlerinde yer vererek reddedilenin, aşağılananın üzerine giderek onu göstermeye ona yer vermeye çalışır. Şiddet üzerine ise bu resimde olduğu gibi yere düşmüş kadın yüzleri, bedenleri ile kadınların yaşadıklarına da tanıklık etmemizi ister. Oskay'ın da (1996, s.186) belirttiği gibi;

“...insan ile insanın arasındaki ilişkinin şiddete dayalı bir ilişki olması, taraftarlardan birinin Hayat karşısındaki konumunun değişmesiyle; Hayatın öznesi olma şansını yitirmesiyle oluşmaktadır."

Başka çalışmalarında kadın bedeninin sıkıştırılmasından yola çıkarak bedeninin sıkışma, deforme olma biçimlerine de rastlarız.

\section{Ida Applebroog}

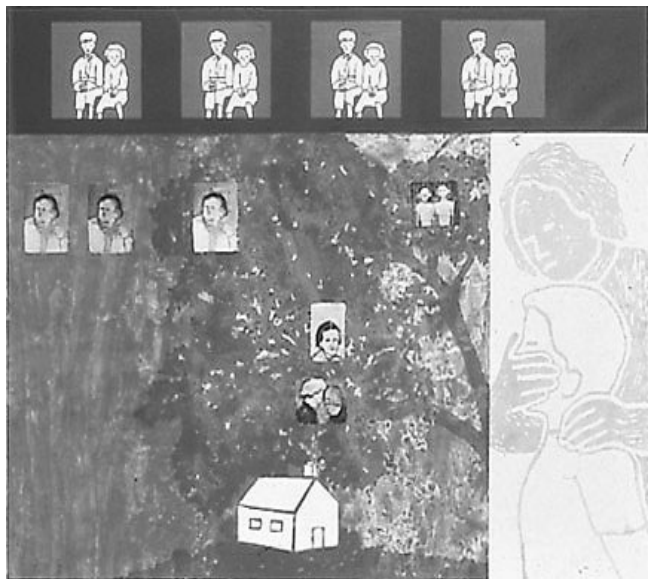

Ida Applebroog, Söz Ölmeyeceğim, (Promise I Won't Die?), 1987, Litografi ve Karlşık Teknik, $36 x$ 48 inches edition of 45

Ida Applebroog, resim, yerleştirme, video art yapmaktadır. Resimlerini grafiksel biçimlerle resimsel pentürü birleştirerek yapmaktadır. Evin etrafi, herkes sessizlik içindedir. Ama en önemlisi 
ağzı tutularak sessizliğe boğulmak istenen her zaman olduğu gibi çocuktur. Bu çalışmasında olduğu gibi, Kurban/Cennet adlı bir çalışması da yine anne, baba ve çocuk ilişkilerinde öldürme ve yaşama üzerinedir.

"Bu resimler, modern hayatın yalnızlık, muhtaçlık, güç, cinsellik, nükleer tehdit çocukların korunması gibi politik sorunlarla ilgilidir. (Smith, 1991)

\section{Sonuç}

Özel alanda yaşanan iktidar ilişkilerinin bir biçimi olan kadının; öne çıkarılan güzelliği ve anneliği ile nesne olarak kabul edilmesi, çocuğa ve kadına taciz, bedensel şiddet gibi birçok durum günümüz kadın sanatçılarının eleştirel ve provokatif işlerinin konusunu oluşturmuştur.

$\mathrm{Bu}$ sanatçıların çalışmalarında, kendilerinin ait oldukları cinsel kimlik sorunlarını, bedenleri kullanarak ve toplumsal cinsiyet kodlarını redderek etkili işler ürettiklerini görürüz. Sanatcılar bunu yaparken erkeklerin iktidarda olmasını amaçlayan hatta onun için kurulmuş gerçeğin eleştirilmesinde geçmişe göre daha cesaretli olmuşlardır.

\section{Kaynakça}

Avcar Savran, G. (2004). Beden Emek Tarih Kanat Kitap. İstanbul: Pusula Yayıncılık.

Ergüven, M. (1997). Görmece. İstanbul: Metis Yayınları.

Foucault, M. (1993). Cinselliğin Tarihi (H. Tufan, Çev.). Afa Yayınları.

Foucault, M. (2005). Özne Ve İktidar (I. Ergüden ve O. Akınbay, Çev.). İstanbul: Ayrıntı Yayınları.

Oskay, Ü. (1996), Şiddet. Cogito Üç Aylık Düşünce Dergisi, Sayı.6-7, Kış Bahar.

Smith, R. (1991). Ida Applebroog New York Times, Nov Erişim: < http://cubittartists.org.uk/1993/12/02/ ida-applebroog/>. Erişim Tarihi: 3/10/2013.

Şenol, C. (2007). "İsimsiz" Erişim: http://www.canansenol.com Erişim Tarihi: 11/6/2007.

Yılmaz, M. (2006). Modernizmden Postmodernizme Sanat. Ankara: Ütopya Yayınları. 